\title{
SKULL RADIOGRAPHS AND COMPUTED TOMOGRAPHY SCANS IN CHILDREN AND ADOLESCENTS WITH MILD HEAD TRAUMA
}

\author{
José Roberto Tude Melo', Rodolfo Casimiro Reis², Laudenor Pereira Lemos-Júnior², \\ Assuero Azevedo-Neto², Dalton Willy Santos Oliveira², Felipe René F. Cruz Garcia ${ }^{2}$, \\ Joelson Oliveira Ribeiro ${ }^{2}$, Muryllo de Brito Santos-Neto², Jamary Oliveira-Filho ${ }^{3}$
}

\begin{abstract}
Objective: To identify which pediatric patients with mild head trauma are candidates for skull radiographs or cranial computed tomography (CCT) scans. Method: Patients with mild head trauma aged from 0 to 19 years presenting to the Emergency Department of a trauma centre from Salvador City, Brazil, between May 2007 and May 2008. Results: A total of 1888 mild head trauma patients were admitted; mean age was $7.4( \pm 5.5)$ years. A total of 1956 skull radiographs and 734 CCT scans were performed. About $44.4 \%$ patients with Glasgow coma score (GCS) 13 and $55.4 \%$ with GCS 14 had abnormal CCT scans. In patients with multiple traumas, $16 \%$ had abnormal findings on CCT scans. Conclusion: We strongly recommend routine CCT studies to patients with GCS of 13 and 14 or to multiple trauma victims, independently of score. Routine screening skull radiographs were not useful in the evaluation of mild head trauma patients in this study.
\end{abstract}

KEY WORDS: tomography, radiography, traumatic injury brain, child, adolescent.

\begin{abstract}
Radiografia simples e tomografia computadorizada do crânio em crianças e adolescentes vítimas de traumatismo craniano leve

Resumo - Objetivo: Identificar quais os pacientes na faixa pediátrica com trauma craniencefálico leve são candidatos para a realização de radiografia simples ou tomografia computadorizada do crânio (TCC). Método: Pacientes com trauma craniano leve, entre 0 e 19 anos, admitidos em um centro de referência em traumatologia, na cidade do Salvador, Brasil, entre maio 2007 e maio 2008. Resultados: Foram atendidos 1888 pacientes com trauma craniano leve, com idade média de 7,4 ( $\pm 5,5)$ anos. Um total de 1956 radiografias simples e 734 TCC foram realizadas. Em 44,4\% dos pacientes com escala de coma de Glasgow (GCS) 13 e $55.4 \%$ com GCS 14, tiveram TCC com achados anormais. Em pacientes com múltiplos traumas, $16 \%$ possuiam alterações na TCC. Conclusão: Recomendamos TCC em pacientes com GCS 13 e 14 ou naqueles com traumas múltiplos, independente do GCS. Radiografias simples do crânio como rotina, não foram identificadas como úteis, no presente estudo.
\end{abstract}

PALAVRAS-CHAVE: tomografia, radiografia, trauma cranioencefálico, criança, adolescência.

Mild head trauma is defined as a non-penetrating head lesion in those with a normal or minimally altered neurologic examination, at times associated with a history of loss of consciousness and post-traumatic amnesia ${ }^{1-6}$. Complications of mild head trauma are unusual, but in rare cases it can be life-threatening and require neurosurgical intervention (0.4\%-1.0\%). Cranial computed tomography (CCT) scan is the imaging study of choice, although some considerations about cost, medical staff, patient sedation and proper devices limit its routine use in children and adolescents ${ }^{7-11}$. There are some divergences regarding CCT scan and skull radiograph indications in pediatric population ${ }^{4,6,7,10,11}$.
Due to this lack of consensus about imaging evaluation of children and adolescents with mild head trauma, in the present study we aimed to identify which pediatric patients with mild head injury are the most proper candidates for skull radiographs and CCT scans in an Emergency Department.

\section{METHOD}

Patients and study design

We considered children with mild head trauma all those who had a Glasgow coma score (GCS) ${ }^{12}$ score of 13,14 or 15 , in agreement with the Brazilian Society of Neurosurgery ${ }^{4}$.

\footnotetext{
'Post-Graduation Program in Medicine and Health from Federal University of Bahia, Salvador BA, Brazil (PPgMS-UFBA), Neurosurgeon, PhD Candidate in Medicine (PPgMS-UFBA); ${ }^{2}$ Medical student of the Head Trauma Research Group (UFBA); ${ }^{3}$ Neurologist, PhD in Neurology (University of São Paulo)., São Paulo SP, Brazil.
}

Received 31 March 2008, received in final form 20 June 2008. Accepted 18 July 2008. 
All patients with mild head trauma aged from 0 to 19 years presenting to the Emergency Department of a trauma centre from Salvador City, Bahia, Brazil, between May 2007 and May 2008, were prospectively enrolled in the study.

The study was approved by the Hospital Ethics Committee $\left(n^{\circ} 06 / 07\right)$, and either patients or family members signed informed consent before participating.

\section{Data collection}

A questionnaire was applied on each patient admission and fulfilled until hospital discharge. We assessed the mechanisms of injury, association with multiple trauma, skull radiograph and CCT scan results. The pediatricians who assisted the children in the emergency room defined which radiological exam was necessary. The reports of skull radiographs or CCT scans were provided by neurologists, neurosurgeons or radiologists.

\section{Data analyses}

Statistical analysis was done by using SSPS 12.0 for Windows (Statically Package for Social Sciences). Categorical data were analyzed by using $\chi^{2}$ analysis.

\section{RESULTS}

A total of 2600 patients aged from 0 to 19 years with a history of head trauma presented to the Emergency Department in the study period; 1888 (72.6\%) had mild head trauma. Regarding GCS classification, $1.9 \%$ of patients had a GCS $13,4.4 \%$ had a GCS 14 and $93.7 \%$ had a GCS 15 on admission. Mean age was 7.4 years $( \pm 5.5)$ and the majority of cases $(27.9 \%)$ involved patients between 03 and 06 years, followed by patients aged from 11 to 19 years (27.4\%). We observed that 437 (23.1\%) patients had less than 2 years of age.

Patients with mild head trauma were submitted to 978 skull radiographs studies (a total of 1956, including lateral and frontal views) and 734 CCT scans. We registered abnormal skull radiographs in $2.5 \%$ of these patients and simple linear skull fracture was the most frequent finding (2.1\%). In reference to children less than 2 years of age (437 patients), only 11 (2.5\%) had fractures on skull radiographs. Among these eleven patients, 09 were victims of fall from a height and two suffered multiple trauma and were submitted to a CCT scan. Only two patients less than 2 yearsold underwent a neurosurgical procedure and they were victims of isolated head trauma.

Considering CCT scan as the gold-standard imaging study in mild head trauma victims, skull radiographs had a sensitivity of $60 \%$ (Table 1).

Reviewing 734 CCT scans, about $10.9 \%$ had abnormalities and the main findings were fractures $(6.2 \%)$, brain swelling (3.3\%) and extradural hematomas (2.0\%) (Table 2). Among those patients who had abnormal findings on CCT scans, $40.5 \%$ had a history of fall from a height, $37.1 \%$
Table 1. Comparison* between 135 cranial computed tomography (CCT) and skull radiograph in the diagnosis of brain lesions in mild head trauma pediatric patients (Salvador City, Bahia, Brazil, 2007/2008).

\begin{tabular}{lcc}
\hline & \multicolumn{2}{c}{ CCT scan } \\
\cline { 2 - 3 } & Abnormal & Normal \\
\hline Skull radiograph** & & \\
Abnormal & 25 & 7 \\
Normal & 17 & 86 \\
\hline
\end{tabular}

*Here we included only the patients who were submitted to both skull radiograph and CCT scan; ** Skull radiograph had a sensitivity of $60 \%$ and a specificity of $92 \%$ when compared to CCT scan.

Table 2. Imaging studies* in children and adolescents with mild head trauma at Salvador, Bahia, Brazil, 2007/2008.

\begin{tabular}{lcc}
\hline Imaging study & $\mathrm{n}$ & $\%^{* *}$ \\
\hline Skull radiograph & & \\
$\quad$ Normal & 931 & 49.3 \\
Simple linear fracture & 40 & 2.1 \\
Depressed fracture & 7 & 0.4 \\
Total & 978 & 51.8 \\
Cranial computed tomography (CCT) scan & & \\
Normal & 529 & 28.0 \\
Abnormal*** & 205 & 10.9 \\
Simple linear fracture & 118 & 6.2 \\
Brain swelling & 62 & 3.3 \\
Acute extradural hematoma & 37 & 2.0 \\
Depressed fracture & 36 & 1.9 \\
Contusion & 28 & 1.5 \\
Others**** & 47 & 2.5 \\
Total & 734 & 38.9 \\
\hline
\end{tabular}

*A total of 1956 skull radiographs (which included frontal and lateral views) and 734 cranial computed tomography (CCT) scans were performed; **Percent of all admitted patients; ${ }^{* * * 93}$ patients had at least two abnormal findings on CCT scans; ****Subarachnoid hemorrhage and/ or acute subdural hematoma and/or pneumoencephalus.

were victims of traffic accidents and $6.3 \%$ had a groundlevel fall history. Only 48 (2.5\%) of all patients underwent a neurosurgical procedure.

Concerning GCS classification, $44.4 \%$ of patients with GCS 13 had abnormal findings on CCT scan $\left(\chi^{2}=12.2\right.$, $\rho=0.01$ ); among those with GCS $14,55.4 \%$ had altered CCT $\operatorname{scan}\left(\chi^{2}=48.9, \rho=0.01\right)$, and only $8.1 \%$ of patients with GCS 15 had abnormal CCT scan.

We also evaluated if multiple trauma was associated with a higher frequency of abnormal CCT scans. Among patients with isolated mild head trauma, $8.8 \%$ had abnormal findings on CCT scans, against $16 \%$ of patients with multiple trauma $\left(\chi^{2}=13.4 ; \rho=0.05\right)$. One patient with mild head trauma died during the study. 


\section{DISCUSSION}

Some previous studies reported children and adolescents as the main victims of head trauma ${ }^{13}$, as well as the predominance of mild cases among patients with head trauma ${ }^{2,10,13,14}$. The rational use of imaging studies in the evaluation of mild head trauma victims is not well established and a consensus regarding skull radiographs and CCT scan use on patients with a GCS of 15 is lacking ${ }^{2,4,14-17}$. As a result, some imaging studies are done with no indication, elevating hospital costs.

Some authors such as Schutzman et al. ${ }^{15}$ and Haydel et al. $^{18}$ noticed that, among victims of mild head trauma, 3-7\% had abnormal CCT scans. We showed here a rate of $10.9 \%$, which raise the need of a better identification of candidates for CCT scans. It is important to notice, therefore, that patients with GCS 13 or 14 must always be submitted to a CCT study, since radiological abnormalities are more frequent in this group of patients.

Skull radiographs were abnormal in a lower frequency (2.5\%) when compared to CCT scans and had a low sensitivity, which is in agreement with some studies that show its lack of importance as a routine screening study in patients with mild head trauma ${ }^{17,19-21}$. Lloyd et al. ${ }^{17}$ observed that neurological examination has a higher sensitivity than skull radiographs with respect to the investigation of intracranial lesions.

Subdivision of mild head trauma in categories, such as high, middle and low risk of developing intracranial lesions, is important to better guide the evaluation of these patients ${ }^{4,15,16}$, avoiding unnecessary exposure to ionizing radiation, family anxiety, patient emotional stress and high hospital costs ${ }^{17}$.

We showed that fall from a height was the most important mechanism of injury associated with abnormal findings on CCT scans; however, we could not specify how height the patients fell. Schutzman et al. ${ }^{15}$ reported that there is a low risk of intracranial lesion in the subgroup of patients that fall from a height less than 3 feet, who have no signs or symptoms at least 2 hours after the injury and that are older than 6 months of age.

The higher incidence of abnormal CCT scans in multiple trauma patients is probably due to more severe mechanisms of injury involved in these accidents when compared to isolated head trauma ones. This tendency was observed by other authors as well 1,15-17,19. $^{\text {. }}$

The limitations of this study should be noted. First of all, this was a single-center study, and so the results shown here may not necessarily be generalized to all centers and populations. Second, the imaging studies results were given not only by radiologists, but also by neurologists and neurosurgeons, and thus some image misinterpretation may have had occurred.
In conclusion, proper identification of patients with low, middle or high risk of developing intracranial lesion is crucial to a better evaluation and management of patients with mild head trauma, therefore avoiding unnecessary imaging studies. Here we showed that the subgroup of mild head trauma patients with higher risk of developing intracranial lesions include multiple trauma victims (independently of GCS ), patients that had a history of fall from a height or traffic accidents and those with GCS 13 and 14; hence, we strongly recommend CCT scans for these patients. Screening skull radiographs were not useful in the evaluation of mild head trauma patients in this study, although their role is still to be determined in patients less than 2 years-old.

\section{REFERENCES}

1. Smits M, Dippel DW, de Haan GG, et al. External validation of the Canadian CT Head Rule and the New Orleans Criteria for CT scanning in patients with minor head injury. JAMA 2005; 294:1519-1525.

2. Macedo KC. [Clinic and epidemiologic characteristics of children and adolescents with mild head trauma and factors associated with skull fracture and brain injury]. Belo Horizonte, 2006. Master dissertion Federal University of Minas Gerais, Brazil.

3. American College of Surgeons Committee on Trauma. Initial assessment and management. In: Advanced trauma life support: reference manual. 4.Ed. Chicago: American College of Surgeons, 1994:17-37.

4. Brazilian Society of Neurosurgery. [Diagnosis and management of patients with mild head trauma]. Guidelines Project, 2001. Available online at http: / / www.portalmedico.org.br/diretrizes /100_diretrizes / traumatismo_craniencefalico_leve.pdf. Accessed on January 29 $9^{\text {th }}, 2007$.

5. Brazilian Society of Neurosurgery. [Diagnosis and management of patients with moderate head trauma]. Guidelines Project, 2001. Available online at http: / / www.portalmedico.org.br/diretrizes/100_diretrizes / traumatismo_craniencefalico_leve.pdf. Accessed on January 29 $9^{\text {th }}, 2007$.

6. American Academy of Pediatrics. Minor head injuries in children. Available online at http: / / www.aap.org/ healthtopics/ safety.cfm. Accessed on August 12 2007.

7. Glauser J. Head injury: which patients need imaging? Which test is best? Cleveland Clin J Med 2004;71:353-357.

8. Varela Hernandez A, Pardo Camacho G, Medrano García R, Rivero Garcia C. [Tomographic findings in mild head trauma]. Rev Mex Neuroc 2005;6:120-123.

9. Lee B, Newber A. Neuroimaging in traumatic brain Imaging. J Am Soc Exp NeuroTherap 2005;2:372-383.

10. American Academy of Pediatrics. The management of minor closed head injury in children. Committee on quality improvement, American Academy of pediatrics; Commission on clinical polices and research, American of Family Physicians. Pediatrics 1999;104:1407-1415.

11. Blackwell CD, Gorelick M, Bandyopadhyay S, Kuppermann N. Pediatric head trauma: changes in use of computed tomography in emergency departments in the United States over time. Ann Emerg Med 2007;49: 320-324.

12. Teasdale G, Jennett B. Assessment of coma and impaired consciousness: a practical scale. Lancet 1974;13:81-83.

13. Melo JRT, Santana DLP, Pereira JLB, Ribeiro TF. Traumatic brain injury in children and adolescents at Salvador City, Bahia, Brazil. Arq Neuropsiquiatr 2006;64:994-996.

14. Aitken ME, Herrerias CT, Davis R, et al. Minor head injury in children: current management practices of pediatricians, emergency physicians, and family physicians. Arch Pediatr Adolesc Med. 1998;152:1176-1180.

15. Schutzman SA, Barnes P, Duhaime AC, et al. Evaluation and management of children younger than two years old with apparently minor head trauma: proposed guidelines. Pediatrics 2001;107:983-993.

16. Stiell IG, Wells GA, Vandemheen K, et al. The Canadian CT Head Rule for patients with minor head injury. Lancet 2001;357:1391-1396.

17. Lloyd DA, Carty H, Patterson M, Butcher CK, Roe D. Predictive value of skull radiography for intracranial injury in children with blunt head injury. Lancet 1997;349:821-824

18. Haydel, MJ, Preston CA, Mills TJ, Luber S, Blaudeau E, DeBlieux, P. Indications for computed tomography in patients with minor head injury. N Engl J Med 2000;343:100-105.

19. Hofman PAM, Nelemans P, Kemerink GJ, Wilmink JT. Value of radiological diagnosis of skull fracture in the management of mild head injury: meta-analysis. J Neurol Neurosurg Psychiatry 2000;68:416-422.

20. Leonidas JC, Ting W, Binkiewicz A, Vaz R, Scott M, Pauker SG. Mild head trauma in children: when is a roentgenogram necessary? Pediatrics 1982;69:139-143.

21. Homer CJ, Kleinman L. Technical report: minor head injury in children. Pediatrics 1999;104:78. 